\title{
Spatial Ability Analysis of Students in Applying the Van Hiele Theory with Autograph Media Assisted
}

\author{
Dewi Hayani Hutagalung, Bornok Sinaga, Hermawan Syahputra \\ Postgraduate Mathematics Education Study Program, State University of Medan \\ Medan, North Sumatra, Indonesia
}

\begin{abstract}
This study aims to describe the level of spatial ability of the VIII grade students of SMP Wiraswasta Batang Kuis after the implementation of the Van Hiele theory with the help of autograph media and to determine the level of difficulty of students in solving spatial problems in learning Van Hiele theory with autograph assistance. Batang Quiz, totaling 25 students. The research instrument was a test of spatial ability and interview guidelines. Data analysis was performed using the Miles and Huberman model. Of the 23 students of class VIII SMP Wiraswasta Batang Kuis who took the test, 15 students (65.21\%) with low spatial ability, 4 students (17.39\%) who had moderate spatial ability levels. high spatial ability as many as students $(17.39 \%)$. Based on this, there are still many students who have a low level of spatial ability. Difficulties experienced by S-1s with low levels of proficiency are in facts, concepts, operations and principles, as well as S-2s with low levels of spatial abilities, the difficulties experienced in operations and principles. Students with low levels of spatial ability, namely S-3 and S-4, experience the same difficulties, namely in the concepts and principles section. Furthermore, S-5 with a high level of spatial ability experienced conceptual difficulties, and S-6 with a high level of spatial ability had no difficulty at all. Likewise S-2 with a low level of spatial difficulty experienced on operations and principles. Students with low levels of spatial ability, namely S-3 and S-4, experience the same difficulties, namely in the concepts and principles section. Furthermore, S-5 with a high level of spatial ability experienced conceptual difficulties, and S6 with a high level of spatial ability had no difficulty at all. Likewise S-2 with a low level of spatial difficulty experienced on operations and principles. Students with low levels of spatial ability, namely S-3 and S-4, experience the same difficulties, namely in the concepts and principles section. Furthermore, S-5 with a high level of spatial ability experienced conceptual difficulties, and S-6 with a high level of spatial ability had no difficulty at all.
\end{abstract}

Keywords: Spatial Ability, Van Hiele, Autograph

DOI: $10.7176 / \mathrm{JEP} / 12-2-07$

Publication date: January $31^{\text {st }} 2021$

\section{PRELIMINARY}

Mathematics as a school subject is considered to play an important role in shaping students to be better, because mathematics is a medium for analyzing thoughts for something logical and systematic (Malau, et al, 2017: 215). The spread of competency standards for junior high school education units, which get the largest portion is geometry (41\%) compared to other materials such as algebra $(37 \%)$, numbers $(15 \%)$, and statistics and opportunities (7\%) (Saputri, et al, 2017 : 2). Based on the data above, geometry has a greater study for students than other branches of mathematics.

One of the objectives of learning geometry as described by Saputri, et al, (2017: 2) is to develop awareness of spatial abilities. Mathematical spatial ability is the ability to imagine, compare, predict, determine, construct, represent, and find information and visual stimuli in the context of the room (Zarkasyi, 2018: 85). Amanda and Syahputra (2019: 49) explain that spatial ability is the individual's ability to see and imagine space objects by simply making pictures of these space objects on paper. This ability requires student indicators to be able to state the position between the elements of a shape, identify and clarify geometric drawings, imagine the shape or position of a geometric object seen from a certain point of view,

But in fact it is inversely proportional to the facts in the field. Amanda and Syahputra (2019: 50) explain that students' spatial abilities are still low, this is because the desire of students to take part in learning is still low due to the use of inappropriate learning models. So far, teachers still use conventional strategies that are only teachercentered so that the process of using classroom learning is less fun. Students still have difficulty mentioning the properties of the cube and block. Students still have difficulty applying the formula for surface area and volume of cubes and blocks to the problem.

This is in line with the results of preliminary observations made by the author at SMP Wiraswasta Batang Kuis, based on the results of the observation that the spatial ability of class VIII students is still low, students do not understand the material related to geometry, especially how to connect the properties that exist in the building space. , rotating a shape and also connecting objects with one another in a form of space. So it can be said that students still have difficulty solving problems related to geometry material, especially in flat side space building. One of the indicators of spatial ability that is still low is Spatial Visualization, which is the ability of students to 
determine the composition of an object after being manipulated by its position and shape.

There are several theories that can be applied by educators to convey material in learning. This learning theory can also be applied to mathematics learning. To improve students' spatial abilities, one of the learning theories that can be used is the Van Hiele theory. Theory (Izzati, et al, 2017).

Based on Van Hiele's theory, students will go through five hierarchical levels of thinking in understanding geometry. The five levels (levels) are: level 0 (visualization), at this level students can name and recognize shapes with geometric appearances, level 1 (analysis), at this level students can determine the properties of a shape by observing, measuring , drawing and modeling experiments, level 2 (informal deduction), at this level students can see the relationship between the properties of a geometric shape and the properties between several geometric shapes, level 3 (deduction). not only accepting evidence, and level 4 (rigor), at this level students can work in different geometric systems or axioms (Pildayani, et al, 2018).

However, the reality in the field is inversely proportional to the theory presented. Based on Kusniati's research in Sholihah and Afriansyah (2017) that the attainment of the developmental level of geometric thinking according to Van Hiele's theory of 38 children, 28 children are at level 0 (visualization), 9 children are at level 1 (analysis), and 1 child is at level informal deduction. In mathematics learning that is carried out by the teacher, it tends to apply conventional learning. Conventional geometry learning does not consider students' different levels of thinking in geometry. This will inhibit the progress of students' thinking levels and abilities in geometry (Pujiarsih, et al, 2018).

This is also in accordance with the results of preliminary observations made by the author at SMP Wiraswasta Batang Kuis, in the mathematics learning process, especially in the material of geometry, it is seen that the teacher does not teach based on the learning stage of Van Hiele's theory, the teacher only teaches in a conventional way where students become passive, learning becomes teacher-centered. Students just sit quietly and write down everything the teacher gives and at the last stage of learning the teacher gives practice questions.

In mathematics learning, there are six basic principles issued by NCTM, namely equality, curriculum, teaching, learning, assessment and technology. Of these six principles, the media is included in the sixth principle, namely technology. Technology is very necessary in learning mathematics which can affect mathematics teaching and learning activities (Hasibuan, 2016). Hasibuan (2016) continues that technological advances in learning include the use of computers to support differences in learning quality. One of the most effective and efficient tools is to use the Autograph.

Autographas one of the learning media emphasizes the active role of students in learning exploration and investigation (Anim, et al, 2018). Autographs can help students understand learning materials such as probability, statistics, and geometry because autographs have 2D and 3D worksheets. Thus it can be concluded that the use of autograph software can help educators and students in the learning and learning process at school (Batubara, 2018).

However, the fact is that in the learning process the teacher still has not made good use of technology in the mathematics learning process, especially in the material of flat-sided building. In practice, the teacher's mathematics learning process does not provide opportunities for students to construct their own mathematical concepts, students only copy what the teacher does. In addition, students are not given the opportunity to put forward ideas and construct their own in answering the practice questions given by the teacher (Muliyadi, 2019).

Based on the results of observations at Wiraswasta Junior High School, it was found that in the mathematics learning process, especially in the class VIII flat side room building material, the teacher did not use technology in the learning process. In the process, the teacher only uses conventional learning. Conventional learning generally has not utilized interactive media as an aid in maximizing learning. This causes learning to be monotonous, students have difficulty imagining, observing, and drawing objects.

\section{THEORITICAL REVIEW}

\section{Spatial Ability}

Mathematical spatial ability is the ability to imagine, compare, predict, determine, construct, represent, and find information and visual stimuli in the context of the room (Zarkasyi, 2018: 85). This ability requires student indicators to be able to state the position between the elements of a shape, identify and clarify geometric drawings, imagine the shape or position of a geometric object seen from a certain point of view, construct and represent geometric models drawn on a flat plane in spatial context, and investigating a geometric object (Sugiarni, et al, 2018: 95).

The indicators of spatial ability according to Zarkasyi (2018: 85) are as follows:

1. Stating the position between the elements of a space building

2. Identify and classify geometric drawings

3. Imagine the shape or position of a geometric object seen from a certain point of view.

4. Construct and present geometric models drawn on a flat plane in the context of space

5. Investigate a geometric object

In line with this, Maier in Prisnaini (2017), several spatial indicators can be described as follows: 
1. Spatial Perception

2. Spatial Visualization

3. Mind Rotation (Mental Rotation)

4. Spatial Relations

5. Spatial Orientation

\title{
Van Hiele Theory
}

Van Hiele is a scientist from the Netherlands who provides views of children's thinking patterns based on the child's ability to observe geometric objects (Sugiyarti, 2019). Van Hiele's learning theory according to Izzati, et al, (2017) is a learning theory that describes the stages of children's mental development in geometry. Pebrauriska and Fachrudin (2018) explain that Van Hiele's theory is a theory which states that students' geometric thinking levels sequentially go through 5 stages or levels. among others, the stages of visualization, analysis, abstraction (informal deduction), deduction, and rigor. According to Mubassiroh (2016) Van Hiele's learning theory is a theory that measures students' geometric skills through five levels to find out where the thinking ability of students in learning geometry has reached.

In Van Hiele's theory of geometric thinking, students' geometric thinking skills can be improved by giving instructions. The instruction was given in 5 phases of learning geometry. This geometry learning phase is designed to assist the teaching and learning process of geometry in order to improve geometric thinking skills. This phase depends on teacher intervention and teaching material facilities. This happens because an increase in the level of thinking does not occur naturally without the help of the correct learning process (Argaswari, 2018).

Van Hiele in his book entitled The Level Theory Geometric of Van Hiele said that the stages of a child's mindset are divided into 5 levels, from level 0 to 4. Level 0 Recognition or Visualization, level 1 analysis, level 2 ordering or informal deductive, level 3 deduction or formal deductive, and level 4 Rigor (Sugiyarti, 2017). These levels show how a person thinks and what types of geometry are thinking, not how much knowledge the student has (Sugiyarti, 2017).

\begin{abstract}
Autograph
Autographaccording to Karnasih in Ramadhani and Lisma (2019), it is one of the software used in learning mathematics. Autograph software is a medium that can be used to learn about two dimensions, three dimensions, statistics, transformations, geometry, equations, coordinates, differentials, graphs, algebra and others. Media Autograph is a mathematical software that is able to visualize 2-dimensional and 3-dimensional objects, is able to rotate objects, and displays the calculation of the area and volume of three-dimensional objects (Fauziah, 2019).
\end{abstract}

\section{RESEARCH METHODS}

This type of research used in this research is descriptive qualitative research. Denzim and Lincoln (in Moleong, 2017: 5) state that "qualitative research is research that uses a natural setting, with the intention of interpreting phenomena that occur and are carried out by involving various existing methods". This research was conducted at SMP Wiraswasta Batang Kuis, in class VIII in the 2019/2020 academic year with the subject, namely students of class VIII-C, totaling 25 students. The criteria for subject taking are based on the dominant answer pattern in each category of students' mathematical spatial abilities. The object of this research is the students' spatial abilities through the application of Van Hiele learning assisted by Autograph media. The research instrument was a mathematical spatial thinking ability test and interview guide. Data analysis was performed using the Miles and Huberman model.

\section{RESULTS AND DISCUSSION}

The students' spatial ability test questions in this study were arranged based on the five stages of Van Hiele's thinking level, namely: Level 0 (Visualization); Level 1 (Analysis); Level 2 (Formal Deduction); Level 3 (Deduction) Level 4 (Rigor). This test was tested on 23 students of class VIII SMP Wiraswasta Batang Kuis and then checked. From the results of the examination, students will be grouped into five stages of Van Hiele's thinking level, as shown in table 1 as follows.

Table 4.1. Students' Geometry Thinking Level

\begin{tabular}{|c|c|c|}
\hline Level & Number of Students Based on Absent Number & $\begin{array}{c}\text { The number of } \\
\text { students }\end{array}$ \\
\hline 0 & $1,2,3,4,5,6,7,8,10,11,12,15,16,17,18,19,20,21,22,23$ & 20 \\
\hline 1 & $1,2,3,4,5,6,7,8,9,11,12,15,16.17$ & 14 \\
\hline 2 & $1,2,3,4,5,6,7,8,9,11,12,15,16.17$ & 14 \\
\hline 3 & $4,5,6,7,11,12,16,17$ & 8 \\
\hline 4 & $4,5,6,7,11,12,16,17$ & 8 \\
\hline
\end{tabular}

In Table 1, the results of grouping the geometric thinking levels of students are listed based on student absent 
numbers. From table 1, it is obtained the proportion of students' geometric problem solving abilities at each level of thinking in terms of Van Hiele's thinking level. Table 1 above shows that there is a reduction in the number of students who can reach the lowest to the highest level of geometric thinking. So it can be concluded that the higher the level of thinking geometry, the fewer students will be able to achieve it.

After the test is tested, scoring is given to the student worksheets. Scoring of the student's spatial ability test is given based on the scoring guidelines that have been prepared, so the students' spatial ability is obtained after the application of the Van Hiele theory as in table 2 below.

Table 2.Students' Spatial Ability Test Results After the Application of Van Hiele's Theory

\begin{tabular}{|c|c|c|c|c|}
\hline No. & SKSP interval & The number of students & Percentage & Level \\
\hline 1 & $0 \leq \mathrm{SKSP}<65$ & 15 & $65.21 \%$ & Low \\
\hline 2 & $65 \leq \mathrm{SKSP}<80$ & 4 & $17.39 \%$ & Moderate \\
\hline 3 & $80 \leq \mathrm{SKSP}<100$ & 4 & $17.39 \%$ & High \\
\hline
\end{tabular}

Note: SKSP = Spatial Ability Score

Table 2 above shows that of the 23 students who took the test, 15 students (65.21\%) had low spatial ability, $4(17.39 \%)$ students who had moderate spatial ability levels. high level of spatial ability as many as students $(17.39 \%)$. Because there are still many students who have a low level of spatial ability, this shows that there are still many students who make mistakes in solving geometric spatial problems. So it is necessary to explore the difficulties experienced by students who make mistakes in solving geometry problems.

Analysis of students' difficulties in solving spatial problems is carried out on each problem or at each level of geometric thinking. These difficulties are obtained from the results of interviews with researchers with research subjects referring to the answers given by the research subjects. These difficulties are described clearly and sequentially for each problem or each level.

To make it easier to describe the difficulties experienced by research subjects, the six research subjects were given the symbols S-1 to S-6. The selected research subjects are presented in table 4.3. as follows.

Table 4.3. Selected Research Subjects

\begin{tabular}{|c|c|c|}
\hline No. & Research subject & Spatial Ability Level \\
\hline 1 & S-1 & Low \\
\hline 2 & S-2 & \multirow{2}{*}{ Moderate } \\
\hline 3 & S-3 & \multirow{2}{*}{ High } \\
\hline 5 & S-4 & \\
\hline 6 & S-5 & S-6
\end{tabular}

The result is, S-1 has difficulty at the fact, concept, operation and principle stage, $\mathrm{S}-2$ at the concept, operation and principle stage, S-3 and S-4 has difficulty at the concept and principle stage, S-5 at the concept stage, while S-6 didn't have any difficulties at all.

\section{CONCLUSION}

Of the 23 students of class VIII SMP Wiraswasta Batang Kuis who took the test, 15 students (65.21\%) with low spatial ability, 4 students $(17.39 \%)$ who had moderate spatial ability levels. high spatial ability as many as students $(17.39 \%)$. Based on this, there are still many students who have a low level of spatial ability.

Difficulties experienced by S-1s with low levels of proficiency are in facts, concepts, operations and principles, as well as S-2s with low levels of spatial abilities, the difficulties experienced in operations and principles. Students with low levels of spatial ability, namely S-3 and S-4, experience the same difficulties, namely in the concepts and principles section. Furthermore, S-5 with a high level of spatial ability experienced conceptual difficulties, and S-6 with a high level of spatial ability had no difficulty at all.

\section{REFERENCES}

Amanda, A and Edi S. 2019. Development of Learning Tools Using Non-Example Example Learning Model to Improve Spatial Skills at SMPN 1 Sei Bingai. Inspirational Journal. Vol. 5. Number 1.

Anim, et al. 2018. Improving Students' Mathematical Communication Skills Using Problem Possing Model Using Autograph Software. Journal of Pedagogic Matematics. Vol. 3. No.1

Argaswari, DPAD 2018. Research and Development of Van Hiele Theory-Based Geometry Learning Module. Histogram Journal. Vol 2. No. 2.

Coal, IH 2018. Improvement of Concept Understanding Ability through Methods Guided Invention Assisted Autograph Software On Many Variable Calculus Courses at FKIP UMSU. MES Journal. Vol. 4. No.1.

Fauziah, L. 2019. The Effect of Autograph Assisted Van Hiele Learning Model on Students' Spatial Literacy Ability. Thesis Not Published Jakarta: UIN Syarif Hidayatullah.

Hasibuan, NH 2016. Utilization of Autograph as Media Mathematics Learning With Implementing a Learning 
Model Problem Based (PBM). Journal of Light Education. Vol. 2. Number 1.

Izzati, FA, et al. 2017. The Influence of the Application of the Van Hiele Theory Assisted by Wingeom Software on Students' Mathematical Reasoning Ability in Geometry Material. ITEJ Journal. Vol. 2. No.1

Malau, T. M, et al. 2017. Improvement Student's Spatial Ability and Self Confidence Through Inquiy Learning With Geogebra at SMA Negeri 19 Medan. Kreano's Journal. Vol. 8. No.2.

Moleong, LJ 2017. Qualitative Research Methods. Bandung: Youth Rosdakarya.

Mubassiroh, S. 2016. Effectiveness of Applying Van Learning Theory HieleAgainst the Activities and Learning Outcomes of Geometry and Measurement Materials for Class IV SDN Mintaragen 6 Tegal City. Thesis Not Published. Semarang: UNNES

Mulyadi and Yuli A. 2019. Efforts to Improve Student Learning Outcomes Using Autograph Media on Flat Sided Building Materials (BRSD) for Class VIII Students of MTs. Private Kuala District Kuala. Genta Mulia Journal. Vol. X. No.1.

Pebuariska, A and Achmad DF 2018. Class VII Student Problem Solving Ability on the Material The quadrilateral is viewed from Van Hiele's Level of Geometry Thinking. Journal of Axioms. Vol. 9. No.1.

Pildayani, et al. 2018. Profile of Flat Triangular Problem Solving Problems in terms of Van Hiele's Thinking Development Level in SMP Negeri 3 Palu Students. Tadulako Mathematics Education Electronic Journal. Vol. 5. No.3.

Prisnaini, RM 2017. Efforts to Improve Spatial Ability with Learning Cycle Assisted by 3D Cabri Application Class VIII F SMP Muhammadiyah Ajibarang. Unpublished Thesis. Purwokerto: Muhammadiyah University of Purwokerto.

Pujiarsih, et al. 2018. The effectiveness of the application of Van Hiele's learning towards student learning outcomes in the material of tangent fellowship in class VIII SMP Negeri 16 Palu. Journal of Axioms. Vol. 7. Number 1.

Ramadhani and Eryanti, L. 2019. Improving Mathematical Self Efficacy through Autogaph-Based Two Stay Two Stray Cooperative Learning. BSIS Journal. Vol. 1. No.2.

Saputri, L. 2017. Increasing the Spatial Ability and Self Efficacy of Class VIII Students of SMP Negeri 1 Binjai Langkat Regency through STAD Type Cooperative Learning on Wingeom Assisted Geometry Material. Paradikma Journal. Vol. 10. No.3.

Sugiarni, R., et al. 2018. Improving Students' Spatial Mathematics Capability with Geogebra-Assisted Problem Based Learning Model. Journal of Kalamatics. Vol. 3, No.1.

Sugiyarti. 2019. Improving Students' Geometry Thinking Level Based on Learning Phases of the Van Hiele Model Using Three Dimensional Space Building Media. Magistra Journal. Vol. 6, No.1.

Zarkasyi, W. 2018. Mathematics Education Research. Bandung: Refika Aditama. 